\title{
Multimedia Glosses for Enhancing EFL Students' Vocabulary Acquisition and Retention
}

\author{
Samah Zakareya Ahmad ${ }^{1}$ \\ ${ }^{1}$ Faculty of Education, Suez University, Suez, Egypt \\ Correspondence: Samah Zakareya Ahmad, Faculty of Education, Suez University, Suez, Egypt.
}

Received: September 10, 2019 Accepted: November 10, 2019 Online Published: November 12, 2019

doi: $10.5539 /$ elt.v12n12p46

URL: https://doi.org/10.5539/elt.v12n12p46

\begin{abstract}
The present study attempted to investigate the effect of multimedia glosses on EFL students' vocabulary acquisition and retention. Forty-five EFL students were divided into two groups: control $(n=22)$ and experimental $(n=23)$. A vocabulary test was administered to both groups in order to ensure that they were equivalent. Then, all participants attended 12 weekly reading sessions where participants of the experimental group practiced reading computerized texts that included multimedia glosses while participants of the control group practiced reading the same texts but without any glosses. Immediately after the treatment was over, the vocabulary test was administered to both groups in order to evaluate the differences between the two groups in vocabulary acquisition. Moreover, the same test was administered to both groups two weeks after the administration of the posttest with the purpose of evaluating the differences between the two groups in vocabulary retention. The statistical analysis revealed a significant difference between the two groups in both the immediate and the delayed administrations of the vocabulary test. Therefore, it was concluded that multimedia glosses enhanced both vocabulary acquisition and retention among EFL students.
\end{abstract}

Keywords: multimedia glosses, EFL students, vocabulary acquisition, vocabulary retention

\section{Introduction}

\subsection{Problem of the Study}

Vocabulary learning has been identified as one of the most essential components of language learning (Tong, 2017; Webb \& Nation, 2017) and many researchers have considered the role of vocabulary as so crucial for successful reading comprehension (Taj, Ali, Sipra, \& Ahmad, 2017) that the success or failure of the reading process may depend on the knowledge of vocabulary or the absence of it (Barrot, 2013). For Lee and Jeon (2017), the reader must possess a certain amount of vocabulary in order to be able to read and understand authentic texts that contain unknown vocabulary. For them, this can happen when at least $95 \%$ of the words in the text are already known. Therefore, Bleses, Makransky, Dale, Højen, and Ari (2016) as well as Masrai and Milton (2017) believe that learning vocabulary plays an important role not only in the acquisition of second language but also in academic achievement which, according to Xiaohui (2010), constitutes a great challenge and an enormous task for both second language learners and teachers.

Despite the necessity to possess good vocabulary, many EFL learners have problems developing their lexical repertoire to an adequate level that would help them communicate effectively in different situations (Rassaei, 2017). This might be due to the fact that acquiring vocabulary in L2 is rather a difficult and demanding process (Kiliçkaya \& Krajka, 2010) because L2 learners find difficulty making guesses as efficiently as native speakers (Ko, 2012). Saudi EFL learners seem to suffer from the same difficulty. Many studies examined the problem of vocabulary deficiency in EFL Saudi learners (e.g., Al-Khairy, 2013; Al-Murshidi, 2014; Al-Qahtani, 2016; Al-Rabai, 2016; Al-Saif \& Milton, 2012; Hamouda, 2013; Khan, 2016; Milton, 2012; Rafada \& Madini, 2017). In order to find out how serious the problem was, a vocabulary test was administered to a group of EFL students at Jubail College of Education, IAU University. This pilot study revealed that $58 \%$ of these students scored low in vocabulary.

Therefore, the present study's problem is that some EFL students do not possess enough vocabulary that would enable them to communicate effectively. Due to the prevalence of technology and its applications in teaching and learning, the researcher decided to attempt the use of multimedia glosses as a means to improve EFL students' 
vocabulary acquisition and retention.

\subsection{Literature Review}

The concept of glossing has not been largely studied by researchers until late in the $20^{\text {th }}$ century though it is certainly not a new phenomenon (Poole, 2012) and can be traced to the Middle Ages (Hong, 2010). Traditionally, a gloss is referred to as a comment, note, translation, definition, annotation, synonym or brief explanation provided either in L1 or L2 in the margins, footnote, or near the unknown words in order to make technical, difficult, unknown or unusual words in a written text comprehensible (Chen, 2016; Choi, 2016; Ertürk, 2016; Khezrlou, Ellis, \& Sadeghi, 2017; Nation, 2013; O'Donnell, 2012; Schmitt, 2010; Taj et al., 2017; Türk \& Erçetin, 2012; Yousefi \& Biria, 2015; Xiaohui, 2010). The main reason for using glosses is to help learners to comprehend the text and acquire new words (Melhi, 2014; Vela, 2015).

Glosses have several benefits for language learners. First, they help learners avoid guessing that can sometimes be inaccurate (Nation, 2013). Second, they provide learners greater autonomy in their reading (Ha, 2015) as they become less dependent on their teachers because looking at a glossed word depends on their own knowledge of a word (Vela, 2015). Third, they help learners activate their prior knowledge as well as connect it with new knowledge in the text; which can facilitate reading comprehension (Azari, Abdullah, Heng, \& Hoon, 2012b; Farvardin \& Biria, 2011; Hong, 2010; Taylor, 2013a, 2013b) and vocabulary acquisition (Zhao \& Ren, 2017). This is especially important for acquiring incidental vocabulary that learners may ignore while reading (Öztürk \& Yorganci, 2017; Teng, 2019). Finally, they save the effort and time of learners compared to dictionary look-up (Hong, 2010; Vela, 2015). However, there is a downside to traditional glosses, which is that it may get in the way of comprehension (Taylor, 2010). Recently, advances in language learning based on technology have helped educators develop an increased variety of input enhancements (Poole, 2012). By clicking a hyperlinked word in a text, learners can access glosses in different formats (text, pictures, videos, \& sound) and locations in the text (at the side, bottom or top margin, in a pop-up window, \& at the end of the text) (Abu Seileek, 2011). This can be referred to as multimedia glosses (Türk \& Erçetin, 2012; Yanguas, 2009).

Multimedia glosses can find their theoretical foundations within the Multiple Intelligences Theory (MIT), the Dual Coding Theory (DCT), and the Generative Theory of Multimedia Learning (GTML). Howard Gardner's MIT differentiates human intelligence into specific modalities (rhythmic, visual, verbal, logical, kinesthetic, interpersonal, intrapersonal, naturalistic, \& existential) (Gardner, 2011). Using multimedia glosses represents an example of the application of the MIT in education (Sadeghi, 2011) as they can include text, pictures, sound files, videos, and hyperlinks to external websites; thereby helping learners with different types of intelligences (Rouhi \& Mohebbi, 2012b, 2013; Tajeddin \& Chiniforoushan, 2011). Allan Paivio's DCT suggests that if the meaning of a word is visually illustrated, this word will become more memorable (Paivio, 2010). In other words, when information is available in two modes of presentation, it becomes more elaborate and thus more memorable (Shalmani \& Sabet, 2010). Therefore, Boers, Warren, Grimshaw, and Siyanova-Chanturia (2017) suggest that providing multimedia glosses invites more and longer attention to the glosses. Additionally, Mayer's GTML proposes that better learning occurs when people are exposed to multimedia presentations rather than single-medium presentations (Mayer \& Moreno, 2002). For example, presentation of words and pictures simultaneously leads to better learning outcomes (Mayer, 2001). Therefore, the use of multimedia glosses would enter the cognitive system through multiple channels (Yanguas, 2009).

Multimedia glosses have been classified considering different factors. The first is the content factor according to which Boers et al. (2017) classify them into translations in L1, synonyms or definitions in L2, pictures, or combinations of these types. The second factor of classifying multimedia glosses is the factor of multimedia which divides multimedia glosses into textual definitions coupled with video (Hsu, 2018), text with picture (Yanguas, 2009), text with audio (Vadasy \& Nelson, 2012), or text, picture, and audio combined together (Salem, 2006). Finally, considering the factor of location, or physical distance between the gloss and the reading text, multimedia glosses can be divided into pop up, in-text, marginal, and end-of-text glosses (Chen, 2016; Chen \& Yen, 2013).

Multimedia glosses offer the same advantages that textual glosses offer, in addition to some more benefits related to their technological nature. First, they help learners enjoy reading (Vela, 2015) without interrupting the reading flow (Ha, 2015) for the purpose of looking the new words up (Vela, 2015) because information will always be available at the click of a mouse (Abu Seileek, 2011). Second, multimedia glosses are not confined to providing textual information (Khezrlou et al., 2017) as the multimedia environment affords multiple formats through which learners can receive the input to check the meaning of the unknown vocabulary (Aldera \& Mohsen, 2013) through pictures, sounds, videos and so forth (Beach, Hull, \& O'Brien, 2011; Mohsen \& Balakumar, 2011). This 
increases the active processing of L2 input as they provide rehearsal or several inputs to the same word (Vela, 2015). Third, the flexibility of connection methods through hyperlinks provides learners as much information as possible (Chen \& Yen, 2013). Fourth, multimedia glosses can be approached both globally and linearly compared to traditional paper-based glosses that can only be approached linearly (Abu Seileek, 2011). That is, multimedia glosses can appear anywhere on the screen when the reader clicks the target word (Khezrlou et al., 2017). Moreover, they can be shown in a pop-up window (Lee \& Lee, 2015). Finally, the easy access to multimedia glosses (Ertürk, 2016) increases learners' independence (Taylor, 2013b) and makes the reading of authentic texts manageable and interactive (Beach et al., 2011).

Some educators suggest a number of guidelines to be considered by instructors, program developers, and designers when using multimedia glosses. The first guideline is related to the technological aspect of multimedia glosses. That is, learners not accustomed to the use of multimedia glosses need to be trained in how to use the software in the most beneficial way to make sure that they can consult all informational categories available (Hong, 2010). Another guideline is about the proficiency levels of learners to which glosses need to be tailored. In this respect, Nation (2009) recommends using L1 glosses for learners with a vocabulary of less than 2000 words and using L2 glosses for more advanced learners. Moreover, some researchers (e.g., Ariew \& Ercetin, 2004) advise instructors to be careful about using glosses with beginners. They explain that the attentional split between the glosses and information in the reading text may have a negative effect on reading comprehension. The third guideline is about the density of the glossed words in the reading text. Nation (2009) points out that approximately two to five percent of the running words in the text should be glossed. Additionally, Hong (2010) advises instructors to avoid selecting too many words or selecting words based on their personal judgment. Instead, they may gloss the words according to their usefulness and importance in the text. The fourth guideline is about the length of the gloss. For Ariew and Ercetin (2004), one-word glosses may cause problems as some readers either know or do not know the meaning. However, they add, if a longer gloss is used (2-7 words), readers will have a better opportunity to understand its meaning. Finally, glosses should be clear, interesting, and helpful to readers as well as fit the context of the text in which the target words appear (Hong, 2010).

Many studies found multimedia glosses to be effective for improving vocabulary learning (e.g., Çakmak, 2014; Chiu, 2013; Hassan, 2010; Hu, Vongpumivitch, Chang, \& Liou, 2014; Jalali \& Neiriz, 2012; Kongtawee \& Sappapan, 2018; Lee \& Lee, 2015; Lee, Lee, \& Lee, 2016; Lee, Warschauer, Lee, 2017; Loucky \& Tuzi, 2010; Moazzeni, Bagheri, Sadighi, \& Zamanian, 2014, 2015; Moradan \& Vafaei, 2016; Oe \& Alam, 2013; Poole, 2011, 2012; Poole \& Sung, 2016; Rashtchi \& Aghili, 2014; Rassaei, 2018; Razagifard, 2010; Rouhi \& Mohebbi, 2012a, 2013; Salem, 2006; Tabatabaei \& Shams, 2011; Türk \& Erçetin, 2012; Yanguas, 2009; Yun, 2011; Zoi, Bellou, \& Mikropoulos, 2011). However, no study investigated the use of multimedia glosses to improve the vocabulary of Saudi EFL students. Therefore, the present study attempted to investigate the effect of multimedia glosses on Saudi EFL students' vocabulary acquisition and retention.

\subsection{Hypotheses of the Study}

To achieve the aim of the present study, it was hypothesized that:

1) A statistically significant difference would exist between the mean scores of the experimental group and the control group in vocabulary acquisition in favor of the experimental group.

2) A statistically significant difference would exist between the mean scores of the experimental group and the control group in vocabulary retention in favor of the experimental group.

\section{Method}

\subsection{Design}

The design used in the present study is a pretest-posttest control group design which consists of an experimental group $(n=23)$ and a control group $(n=22)$. Both groups were administered to a test of vocabulary before and after the treatment in order to measure vocabulary acquisition. Two weeks after the posttest, participants were tested in vocabulary again in order to measure vocabulary retention.

\subsection{Participants}

Forty-five first-year EFL students at Jubail College of Education, IAU University, participated in the study. They ranged between 14-16 years of age with a mean of 15.23 years. All participants were acquainted to using computers at school.

\subsection{Variables}

The present study includes an independent variable (multimedia glosses) as well as two dependent variables 
(vocabulary acquisition \& vocabulary retention). Below are the operational definitions for the three variables.

\subsubsection{Multimedia Gloss}

A multimedia gloss is a pop-up window which includes a synonym, definition, pronunciation, picture, video, and a hypertext link to external information. This window will appear when a reader clicks on certain difficult or unknown words in a computerized text in order to make these words comprehensible.

\subsubsection{Vocabulary Acquisition}

Vocabulary acquisition is EFL learners' scores on the English vocabulary test administered immediately after the experiment in order to measure their skills in recognizing, understanding and applying the English lexical items taught to them.

\subsubsection{Vocabulary Retention}

Vocabulary retention is EFL learners' scores on the English vocabulary test administered two weeks after the experiment.

\subsection{Instrument}

A vocabulary test was devised by the researcher to be used as: (1) a pretest to ensure the equivalence of the two groups before the treatment, (2) a posttest to measure vocabulary acquisition immediately after the treatment, and (3) a delayed test to measure vocabulary retention two weeks after the treatment. This test consisted of 50 multiple-choice questions, each measuring a target vocabulary. Every question had four options, only one was correct. Every correct answer was awarded one mark for a total of 50 possible marks. The pretest, posttest, and delayed test were the same. The only difference was rearranging the questions and options.

The test was given to a pilot group of 20 students in order to determine item difficulty and test duration. Item difficulty was estimated by dividing the frequencies of incorrect answers by the total number of students. The values of the item difficulty ranged between 0.27 and 0.76 for all test items. On the other hand, the discrimination index was estimated by using inter-item correlation. This correlation was between each item and the total score of the test. The discrimination indexes of all the test items were within acceptable range $(0.10$ and above). It took students 72 minutes to complete the test; therefore, 75 minutes were allotted as the time of the test in the actual study.

To determine the validity of the vocabulary test, it was given to five specialists working in the field of TEFL and their feedback was obtained concerning the wording of the test items as well as the relevance of the items to students' proficiency level. Test reliability was measured by employing Cronbach's Alpha method. The standardized Cronbach's Alpha was 0.87. This ensures the relative internal consistency of the test items.

\subsection{Materials}

Eight reading passages were selected from the specified textbook. In order to determine the vocabulary to be glossed, a pilot study was conducted in which a hardcopy version of the selected texts was given to three reading instructors who read the passages and selected every single or multi-word lexical item they believed students did not know. Instructors selected 167 words which the researcher put in a list and asked 23 students who did not take part in the present study to determine whether each word is known or unknown to each of them. The words that were determined to be unknown to $60 \%$ or more of the students were chosen as target words. After consulting the reading instructors, and the 23 non-participant students, the vocabulary words selected as target words were 114: 56 nouns (49\%), 42 verbs (37\%), and 16 adjectives (14\%). For each glossed word used in the study, the following six types of information were provided:

- The equivalent of the glossed vocabulary, mainly consisting of one word.

- The definition of the word, usually a phrase of 2-6 words. Definitions were extracted from Oxford Advanced Learner's Dictionary (2014) and the American Heritage Dictionary (2015).

- A digital high-resolution picture of the word, from the Internet.

- Audio pronunciation of the word in English.

- A digital video of the glossed word, from the Internet. Videos had almost the same length and quality.

- A hypertext link to an external web page with information about the glossed word.

Great care was exercised to find clear and contextually-appropriate synonyms, definitions, pictures, audios, videos, and links to external web sites. Moreover, these selections were evaluated by two reviewers. Based on their remarks, seven of the videos and 11 of the pictures were changed as they were not clear enough to describe 
the target words. For target words that appeared more than once in a text, only the first occurrence of this target word was glossed.

In order to include multimedia glosses into the selected texts, the researcher used a multimedia editor software called Foreign Language Annotator (FLAn), created by Thibeault (2011). Using FLAn, multimedia texts were generated through integrating multimedia glosses to the selected texts. The texts were displayed on the screen. Following the suggestion of Ali, Wahid, Samsudin, and Idris (2013), black sans serif font (Verdana) on a white background was used for optimal onscreen reading. The glossed words were underlined and blue in color.

When a highlighted word or phrase was clicked, a pop-up window would appear on the right-hand corner of the screen. In order not to interrupt the flow of reading, the text was still available for the reader to see on the screen at any time. This allowed readers to have access to both the reading text and the glosses simultaneously. The pop-up window contained the gloss types mentioned above (i.e., synonym, definition, picture, audio, video, \& hyperlinks). The students were instructed to read the text, click on the highlighted words, and study the glosses that appeared. Readers could view only one gloss at a time. When they clicked a target word, the gloss for this word appeared. When they clicked another target word, the first word disappeared. Three experts in instructional designing evaluated the electronic texts for user-friendliness and made sure that the hyperlinks were working well and would lead to the external websites.

\subsection{Procedures}

Experimental procedures were executed at Jubail College of Education, IAU University, during a 15 -week period. These procedures were carried out in five steps: 1) pretesting, 2) orienting participants, 3) reading sessions, 4) posttesting, and 5) dealayed measurement.

\subsubsection{Pretesting}

The vocabulary test was administered to all participants. Mann-Whitney U-test analysis of pretest data did not indicate a significant difference between the mean scores of the two groups $(U=238 ; p>0.05)$. This confirmed that the two groups were equivalent. The results of the Mann-Whitney U-test of the difference between the groups are summarized in Table 1.

Table 1. Mann-Whitney U-Test of the Difference between the Mean Scores of the Two Groups on the Pretest of Vocabulary Acquisition

\begin{tabular}{llllll}
\hline Group & $\mathrm{N}$ & Mean Rank & Sum of Ranks & Mann-Whitney U & Sig. (2-tailed) \\
\hline Control & 23 & 23.65 & 544 & 238 & 0.733 \\
Experimental & 22 & 22.32 & 491 & & \\
\hline
\end{tabular}

\subsubsection{Orienting Participants}

Before the reading sessions started, participants of the experimental group attended a 45 -minute orientation session in order to become familiarized with the FLAn software. They were trained in how to start the program, how to click on a glossed word to view the different types of glosses, and how to check different types of glosses.

\subsubsection{Reading Sessions}

All participants attended 12 weekly reading sessions in the same place and at the same time in order to reduce the possibility for participants to share what was going on in each group. Each of the two groups had access to a different version of the software. That is, the experimental group used a version that provided multimedia glosses in a popup window while the control group used another version of the software which enabled them to read the same computerized texts (with the same font, color, and background) in a scrolling window without offering any glosses. Target words were underlined for all participants. This would help both groups be equally focused toward the target vocabulary that would later appear in the vocabulary test. However, for the experimental group the underlines words would generate a popup window with multimedia glosses while for the control group they generated nothing. Students in the experimental group were required to read the passages and to consult the multimedia glosses while participants of the control group were required to read the passages and to try to guess the meanings of the target words from context. After reading each passage, participants were required to answer some questions regarding the target vocabulary included in this passage. 


\subsubsection{Posttesting}

Immediately after the reading sessions were finished, all participants were administered to the vocabulary test. The purpose was to evaluate the difference between the two groups in vocabulary acquisition.

\subsubsection{Delayed Measurement}

Two weeks after the administration of the posttest, all participants were administered to the vocabulary test. The purpose was to evaluate the difference between the two groups in vocabulary retention.

\section{Results}

The difference between the mean scores of the two groups on the vocabulary posttest was analyzed using Mann-Whitney U-test which showed that this difference was statistically significant in favor of the experimental group $(\mathrm{U}=125 ; \mathrm{p}<0.05)$. See Table 2 .

Table 2. Mann-Whitney U-Test of the difference between the mean scores of the two groups on the posttest of vocabulary acquisition

\begin{tabular}{llllll}
\hline Group & N & Mean Rank & Sum of Ranks & Mann-Whitney U & Sig. (2-tailed) \\
\hline Control & 23 & 17.43 & 401 & 125 & 0.004 \\
Experimental & 22 & 28.82 & 634 & & \\
\hline
\end{tabular}

Moreover, the difference between the mean scores of the two groups on the vocabulary delayed measurement was analyzed using Mann-Whitney U-test which showed that this difference was statistically significant in favor of the experimental group $(\mathrm{U}=126 ; \mathrm{p}<0.05)$. See Table 3 .

Table 3. Mann-Whitney U-Test of the difference between the mean scores of the two groups on the delayed measurement of vocabulary

\begin{tabular}{llllll}
\hline Group & $\mathrm{N}$ & Mean Rank & Sum of Ranks & Mann-Whitney U & Sig. (2-tailed) \\
\hline Control & 23 & 17.48 & 402 & 126 & 0.004 \\
Experimental & 22 & 28.77 & 633 & & \\
\hline
\end{tabular}

\section{Discussion}

The present study attempted to investigate how multimedia glosses would affect EFL students' vocabulary acquisition and retention. The study included two hypotheses. The first one stated that a statistically significant difference would exist between the mean scores of the experimental group and the control group in vocabulary acquisition in favor of the experimental group. The statistical analysis revealed a significant difference between the two groups in the immediate administration of the vocabulary test. The second hypothesis of the study stated that a statistically significant difference would exist between the mean scores of the experimental group and the control group in vocabulary retention in favor of the experimental group. The statistical analysis also revealed a significant difference between the two groups in the delayed administration of the vocabulary test.

The findings of the present study agree with the results of many studies which revealed the effectiveness of multimedia glosses in improving vocabulary learning (e.g., Çakmak, 2014; Chiu, 2013; Hassan, 2010; Hu, Vongpumivitch, Chang, \& Liou, 2014; Jalali \& Neiriz, 2012; Kongtawee \& Sappapan, 2018; Lee \& Lee, 2015; Lee, Lee, \& Lee, 2016; Lee, Warschauer, Lee, 2017; Loucky \& Tuzi, 2010; Moazzeni, Bagheri, Sadighi, \& Zamanian, 2014, 2015; Moradan \& Vafaei, 2016; Oe \& Alam, 2013; Poole, 2011, 2012; Poole \& Sung, 2016; Rashtchi \& Aghili, 2014; Rassaei, 2018; Razagifard, 2010; Rouhi \& Mohebbi, 2012a, 2013; Salem, 2006; Tabatabaei \& Shams, 2011; Türk \& Erçetin, 2012; Yanguas, 2009; Yun, 2011; Zoi, Bellou, \& Mikropoulos, 2011) while they disagree with a less number of studies which found no significant effect for multimedia glosses on vocabulary gains (e.g., Boers, Warren, He, \& Deconinck, 2017; Faramarzi, Elekaei, \& Koosha, 2014; Sato, 2016; Sato \& Suzuki, 2010). This goes along with Choi's (2016) contention that empirical findings to date have demonstrated favorable effects of multimedia glosses on learners' vocabulary knowledge.

A possible explanation for the results of this study is that glossing difficult vocabulary helps learners acquire their meaning. This was proved by some studies (e.g., Al-Ghafli \& Hussain, 2011; Arpaci, 2016; Azari, 2012; 
Azari, Abdullah, Heng, \& Hoon, 2012a; Ghabanchi \& Ayoubi, 2012; Ghahari \& Heidarolad, 2015; Huang, 2010; Jung, 2016; Ko, 2012; Salehi \& Naserieh, 2013; Todd, 2014; Tong, 2017; Zhao \& Ren, 2017). This also goes along with Barcroft's (2015) belief that activities which introduce the meanings of words to learners in the early phase of learning the words enhance the acquisition of word meanings.

Another explanation for the results of this study is that multimedia glosses might have responded to participants' preferences to use technology in learning which might have a positive influence on their vocabulary learning. This explanation has been supported by many previous studies which found a significant effect for using technology on vocabulary learning (Alavinia \& Qoitassi, 2013; Alemi, Sarab, \& Lari, 2012; Chen \& Chung, 2012; Fehr et al., 2012; Hayati, Jalilifar, \& Mashhadi, 2013; Korat \& Shamir, 2012; Maftoon, Hamidi, \& Sarem, 2015; Mahsefat \& Homaie, 2012; Nikoopour \& Kazemi, 2014; Sun \& Yang, 2012; Wang \& Shih, 2015; Ward \& Williams-Rossi, 2012; Yanguas, 2012).

Another possible explanation is the use of pictures in the multimedia glosses. The inclusion of pictorial glosses better reveals the underlying meanings to learners (Morett, 2019; Shalmani \& Razmjoo, 2015) as well as enhances learners' retention of word meaning (Boers et al., 2017); thereby leading to better vocabulary gains (Türk \& Erçetin, 2012). This explanation is in tune with the assumptions of the DCT (Paivio, 2007) which proposes that vocabulary glossed with both text and pictures are acquired better than those glossed with text only (Sadoski \& Paivio, 2013). According to this theory, pictures are more easily retrieved from memory than are words and recall is enhanced thanks to word-image association (Reed, 2010).

A further explanation for the present findings is the use of video in the glosses. In this context, Aldera and Mohsen (2013), Jelani and Boers (2018) as well as Cokely and Muñoz (2019) found out that using videos is an effective means that can enhance vocabulary acquisition. This explanation is supported by the assumptions of the GTML (Mayer, 2005) which assumes that the working memory has a limited capacity, therefore there should be a simultaneous processing of verbal and visual information (Türk \& Erçetin, 2012).

Finally, the improvement in vocabulary acquisition and retention in the present study may have resulted from the positive learning atmosphere that accompanied the use of the multimedia glosses as participants had the opportunity to select the medium they liked while they were looking for the meaning of the glossed words. They could select among text, pictures, audio clips, video clips, and hyperlinks to websites. This might have been suitable for participants with different preferences and learning styles, so that information can be offered to learners in the mode they prefer or need. This explanation agrees with Tight's (2010) opinion that vocabulary instruction through multiple modalities is beneficial for learners of different style preferences. It also goes in harmony with the principles of Gardner's MIT which emphasizes the necessity to provide learners with material presented in multiple ways and modes to facilitate effective learning (Gardner, 2011).

\section{Conclusion, Recommendations, and Suggestions for Further Research}

Based on the results of the current study, the researcher concluded that multimedia glosses enhanced both vocabulary acquisition and retention among EFL students. The researcher also recommended that: (1) multimedia glosses should be used in teaching EFL vocabulary, (2) vocabulary learning should go along with students' preferences to use their smart phones and personal computers in learning, (3) vocabulary learning should be given enough attention in EFL courses, (4) EFL teachers should enhance their technological skills to be able to cope up with instructional enhancements and innovations, and (5) teachers should take into consideration the differences in EFL learners' learning preferences and styles. Moreover, she suggested conducting further research to examine (1) a comparison between traditional paper-based glosses and multimedia glosses on EFL vocabulary learning, (2) the effect of multimedia glosses on EFL reading comprehension, (3) the effect of multimedia glosses on students' engagement, and (4) the effect of multimedia glosses on students' attitude towards using technology in learning.

\section{References}

Abu Seileek, A. (2011). Hypermedia annotation presentation: The effect of location \& type on the EFL learners' achievement in reading comprehension \& vocabulary acquisition. Computers \& Education, 57, 1281-1291. https://doi.org/10.1016/j.compedu.2011.01.011

Alavinia, P., \& Qoitassi, K. (2013). On the viability of vocabulary learning enhancement through the implementation of MALL: The case of Iranian EFL learners. Journal of Language Teaching \& Research, 4(2), 412-426. https://doi.org/10.4304/jltr.4.2.412-426

Aldera, A., \& Mohsen, M. (2013). Annotations in captioned animation: Effects on vocabulary learning \& listening skills. Computers \& Education, 68, 60-75. https://doi.org/10.1016/j.compedu.2013.04.018 
Alemi, M., Sarab, M., \& Lari, Z. (2012). Successful learning of academic word list via MALL: Mobile assisted language learning. International Education Studies, 5(6), 99-109. https://doi.org/10.5539/ies.v5n6p99

Al-Ghafli, A. \& Hussain, M. (2011). The effect of mediated glosses on vocabulary retention \& reading comprehension with English language learners in Saudi Arabia (Unpublished doctoral dissertation). University of Kansas.

Ali, A., Wahid, R., Samsudin, K., \& Idris, M. (2013). Reading on the computer screen: Does font type has effects on web text readability? International Education Studies, 6(3), 26-35. https://doi.org/10.5539/ies.v6n3p26

Al-Khairy, M. (2013). Saudi English-major undergraduates' academic writing problems: Al-Taif University perspective. English Language Teaching, 6(6), 1-12. https://doi.org/10.5539/elt.v6n6p1

Al-Murshidi, G. (2014). Emirati \& Saudi students' writing challenges at US universities. English Language Teaching, 7(6), 87-95. https://doi.org/10.5539/elt.v7n6p87

Al-Qahtani, A. (2016). Why do Saudi EFL readers exhibit poor reading abilities? English Language \& Literature Studies, 6(1), 1-15. https://doi.org/10.5539/ells.v6n1p1

Al-Rabai, F. (2016). Factors underlying low achievement of Saudi EFL learners. International Journal of English Linguistics, 6(3), 21-37. https://doi.org/10.5539/ijel.v6n3p21

Al-Saif, A., \& Milton, J. (2012). Vocabulary input from school textbooks as a potential contributor to the small vocabulary uptake gained by English as a foreign language learners in Saudi Arabia. The Language Learning Journal, 40(1), 21-33. https://doi.org/10.1080/09571736.2012.658221

American Heritage Dictionary (5th ed.). (2015). Boston: Houghton Mifflin Harcourt.

Ariew, R., \& Ercetin, G. (2004). Exploring the potential of hypermedia annotations for second language reading. Computer Assisted Language Learning, 17, 237-259. https://doi.org/10.1080/0958822042000334253

Arpaci, D. (2016). The effects of accessing L1 versus L2 definitional glosses on L2 learners' reading comprehension \& vocabulary learning. Eurasian Journal of Applied Linguistics, 2(1), 15-29. https://doi.org/10.32601/ejal.460988

Azari, F. (2012). Review of effects of textual glosses on incidental vocabulary learning. International Journal of Innovative Ideas, 12(2), 13-24.

Azari, F., Abdullah, F., Heng, C., \& Hoon, T. (2012a). Effects of glosses on vocabulary gain \& retention among tertiary level EFL learners. Retrieved from ERIC database. (ED533228)

Azari, F., Abdullah, F., Heng, C., \& Hoon, T. (2012b). Effects of textual glosses on reading comprehension of low proficiency EFL postgraduates. The English Teacher, 41(1), 42-55.

Barcroft, J. (2015). Lexical input processing \& vocabulary learning. Amsterdam, Netherlands: John Benjamins. https://doi.org/10.1075/1llt.43

Barrot, J. (2013). Revisiting the role of linguistic complexity in ESL reading comprehension: Language, linguistics \& literature. The Southeast Asian Journal of English Language Studies, 19(1), 5-18.

Beach, R., Hull, G., \& O'Brien, D. (2011). Transforming English language arts in a 2.0 world. In D. Lapp, \& D. Fisher (Eds.), Handbook of research on teaching the English language arts. Abingdon: Routledge.

Bleses, D., Makransky, G., Dale, P., Højen, A., \& Ari, B. (2016). Early productive vocabulary predicts academic achievement 10 years later. Applied Psycholinguistics, 37(6), 1461-1476. https://doi.org/10.1017/S0142 716416000060

Boers, F., Warren, P., Grimshaw, G., \& Siyanova-Chanturia, A. (2017). On the benefits of multimodal annotations for vocabulary uptake from reading. Computer Assisted Language Learning, 30(7), 709-725. https://doi.org/10.1080/09588221.2017.1356335

Boers, F., Warren, P., He, L., \& Deconinck, J. (2017). Does adding pictures to glosses enhance vocabulary uptake from reading? System, 66, 113-129. https://doi.org/10.1016/j.system.2017.03.017

Çakmak, F. (2014). Exploring the role of multimedia glosses \& strategy use in second language listening comprehension \& incidental vocabulary learning in a mobile environment (Unpublished doctoral dissertation). Bogazici University, Turkey.

Chen, I. (2016). Hypertext glosses for foreign language reading comprehension \& vocabulary acquisition: Effects of assessment methods. Computer Assisted Language Learning, 29(2), 413-426. https://doi.org/10. 
$1080 / 09588221.2014 .983935$

Chen, C. \& Chung, W. (2012). Research on the learning effects of multimedia assisted instruction on Mandarin vocabulary acquisition for Vietnamese students (Part II): A case study. Educational Research \& Reviews, 7(14), 315-325.

Chen, I. \& Yen, J. (2013). Hypertext annotation: Effects of presentation formats \& learner proficiency on reading comprehension \& vocabulary learning in foreign languages. Computers \& Education, 63, 416-423. https://doi.org/10.1016/j.compedu.2013.01.005

Chiu, Y. (2013). Computer-assisted second language vocabulary instruction: A meta-analysis. British Journal of Educational Technology, 44(2), 52-56. https://doi.org/10.1111/j.1467-8535.2012.01342.x

Choi, S. (2016). Effects of L1 \& L2 glosses on incidental vocabulary acquisition \& lexical representations. Learning \& Individual Differences, 45, 137-143. https://doi.org/10.1016/j.lindif.2015.11.018

Cokely, M., \& Muñoz, C. (2019). Captioned video, vocabulary \& visual prompts: An exploratory study. In C. Herrero, \& I. Vanderschelden (Eds.), Using film \& media in the language classroom: Reflections on research-led teaching. Bristol, UK: Multilingual Matters. https://doi.org/10.21832/9781788924498-008

Ertürk, Z. (2016, April). The effect of glossing on EFL learners' incidental vocabulary learning in reading. Paper presented at the International Conference on Teaching \& Learning English as an Additional Language, GlobELT 2016, Antalya, Turkey. https://doi.org/10.1016/j.sbspro.2016.10.052

Faramarzi, S., Elekaei, A., \& Koosha, M. (2014). On the impact of multimedia glosses on reading comprehension, vocabulary gain, \& vocabulary retention. International Journal of Language Learning \& Applied Linguistics World, 6(4), 623-634.

Farvardin, M., \& Biria, R. (2011). Textual glosses, text types, \& reading comprehension. Theory \& Practice in Language Studies, 1(10), 1408-1415. https://doi.org/10.4304/tpls.1.10.1404-1415

Fehr, C., Davison, M., Graves, M., Sales, G., Seipel, B., \& Sekhran-Sharma, S. (2012). The effects of individualized, online vocabulary instruction on picture vocabulary scores: An efficacy study. Computer Assisted Language Learning, 25(1), 87-102. https://doi.org/10.1080/09588221.2011.586640

Gardner, H. (2011). Frames of mind: The theory of multiple intelligences. London: Hachette.

Ghabanchi, Z., \& Ayoubi, E. (2012). Incidental vocabulary learning \& recall by intermediate foreign language students: The influence of marginal glosses, dictionary use, \& summary writing. Journal of International Education Research, 8(2), 85-96. https://doi.org/10.19030/jier.v8i2.6828

Ghahari, S., \& Heidarolad, M. (2015). Multiple-choice glosses \& incidental vocabulary learning: A case of an EFL context. Reading Matrix, 15(1), 262-273.

Ha, M. (2015). Vocabulary glosses \& second language reading. International Information Institute, 18(6), 2753-2758.

Hamouda, A. (2013). An exploration of causes of Saudi students' reluctance to participate in the English language classroom. International Journal of English Language Education, 1(1), 17-34. https://doi.org/ 10.5296/ijele.v1i1.2652

Hassan, R. (2010). Software application for computer-aided vocabulary learning in a blended learning environment (Unpublished master's thesis). The American University in Cairo, Egypt.

Hayati, A., Jalilifar, A., \& Mashhadi, A. (2013). Using short message service (SMS) to teach English idioms to EFL students. British Journal of Educational Technology, 44(1), 66-81. https://doi.org/10.1111/j.1467-8535. 2011.01260.x

Hong, X. (2010). Review of effects of glosses on incidental vocabulary learning \& reading comprehension. Chinese Journal of Applied Linguistics, 33(1), 56-73.

Hsu, H. (2018). Incidental professional vocabulary acquisition of EFL business learners: Effect of captioned video with glosses. JALT CALL Journal, 14(2), 119-142.

Hu, S., Vongpumivitch, V., Chang, J., \& Liou, H. (2014). The effects of L1 \& L2 e-glosses on incidental vocabulary learning of junior high-school English students. ReCALL, 26(1), 80-99. https://doi.org/10.1017/ S0958344013000244

Huang, S. (2010). Effects of tasks \& glosses on L2 incidental vocabulary learning: Meta-analyses (Unpublished doctoral dissertation). Texas A \& M University. 
Jalali, S. \& Neiriz, A. (2012). Computer-based versus traditional L1 \& L2 glosses. International Journal of Physical \& Social Sciences, 2(9), 188-217.

Jelani, N. \& Boers, F. (2018). Examining incidental vocabulary acquisition from captioned video. International Journal of Applied Linguistics, 169(1), 169-190. https://doi.org/10.1075/itl.00011.jel

Jung, J. (2016). Effects of glosses on learning of L2 grammar \& vocabulary. Language Teaching Research, 20(1), 92-112. https://doi.org/10.1177/1362168815571151

Khan, I. (2016). Difficulties in mastering \& using English for specific purpose (medical vocabulary): A linguistic analysis of working Saudi hospital professionals. International Journal of Education, 8(1), 78-93. https://doi.org/10.5296/ije.v8i1.9163

Khezrlou, S., Ellis, R., \& Sadeghi, K. (2017). Effects of computer-assisted glosses on EFL learners' vocabulary acquisition \& reading comprehension in three learning conditions. System, 65, 104-116. https://doi.org/10. 1016/j.system.2017.01.009

Kiliçkaya, F. \& Krajka, J. (2010). Comparative usefulness of online \& traditional vocabulary learning. The Turkish Online Journal of Educational Technology, 9(2), 55-63.

Ko, M. (2012). Glossing \& second language vocabulary learning. TESOL Quarterly, 46(1), 56-79. https://doi.org/10.1002/tesq.3

Kongtawee, P. \& Sappapan, P. (2018). The effects of L1 \& L2 hypertext glosses on reading comprehension \& vocabulary: Retention among Thai secondary school students. Arab World English Journal, 9(3), 367-380. https://doi.org/10.24093/awej/vol9no3.24

Korat, O., \& Shamir, A. (2012). Direct \& indirect teaching: Using e-books for supporting vocabulary, word reading, \& story comprehension for young children. Journal of Educational Computing Research, 46(2), 135-152. https://doi.org/10.2190/EC.46.2.b

Lee, J., \& Jeon, Y. (2017, February). Effects of L1 \& L2 glosses on Korean English learners' vocabulary learning \& reading comprehension: A meta-analysis. Paper presented at the International Conference on Platform Technology \& Service, Busan, South Korea. https://doi.org/10.1109/PlatCon.2017.7883703

Lee, H. \& Lee, J. (2015). The effects of electronic glossing types on foreign language vocabulary learning: Different types of format \& glossary information. The Asia-Pacific Education Researcher, 24(4), 591-601. https://doi.org/10.1007/s40299-014-0204-3

Lee, H., Lee, H., \& Lee, J. (2016). Evaluation of electronic \& paper textual glosses on second language vocabulary learning \& reading comprehension. The Asia-Pacific Education Researcher, 25(4), 499-507. https://doi.org/10.1007/s40299-015-0270-1

Lee, H., Warschauer, M., \& Lee, J. (2017). The effects of concordance-based electronic glosses on L2 vocabulary learning. Language Learning \& Technology, 21(2), 32-51. https://doi.org/10.4018/jvple.20101 00103

Loucky, J. \& Tuzi, F. (2010). Comparing foreign language learners' use of online glossing programs. International Journal of Virtual \& Personal Learning Environments, 1(4), 31-51.

Maftoon, P., Hamidi, H., \& Sarem, S. (2015). The effects of CALL on vocabulary learning: A case of Iranian intermediate EFL learners. Broad Research in Artificial Intelligence \& Neuroscience, 3(4), 19-30.

Mahsefat, H. \& Homaie, S. (2012). Using internet technology in teaching vocabulary for elementary students. The Iranian EFL Journal, 8(5), 39-51.

Masrai, A. \& Milton, J. (2017). Recognition vocabulary knowledge \& intelligence as predictors of academic achievement in EFL context. TESOL International Journal, 12(1), 128-142.

Mayer, R. (2001). Multimedia learning. Cambridge: Cambridge University Press. https://doi.org/10.1017/CBO 9781139164603

Mayer, R. (2005). The Cambridge handbook of multimedia learning. New York: Cambridge University Press. https://doi.org/10.1017/CBO9780511816819

Mayer, R., \& Moreno, R. (2002). Animation as an aid to multimedia learning. Educational Psychology Review, 14(1), 87-99. https://doi.org/10.1023/A:1013184611077

Melhi, A. (2014). Effects on \& predictability of computer-mediated glosses in reading comprehension of EFL college students. Reading, 14(2), 65-77. 
Milton, J. (2012). The vocabulary knowledge of university students in Saudi Arabia. TESOL Arabia Perspectives, 19(3), 13-19.

Moazzeni, Z., Bagheri, M., Sadighi, F., \& Zamanian, M. (2014). The effect of different gloss types on incidental vocabulary retention of Iranian EFL students. International Journal of Language Learning \& Applied Linguistics World, 5(2), 396-415.

Moazzeni, Z., Bagheri, M., Sadighi, F., \& Zamanian, M. (2015). The effect of glossing technique on incidental vocabulary retention: A comparison between textual \& multi-media glosses. Modern Journal of Language Teaching Methods, 5(1), 222-229.

Mohsen, M. \& Balakumar, M. (2011). A review of multimedia glosses \& their effects on L2 vocabulary acquisition in CALL literature. ReCALL, 23(2), 135-159. https://doi.org/10.1017/S095834401100005X

Moradan, A. \& Vafaei, M. (2016). The effect of glosses on incidental vocabulary learning of Iranian EFL learners. International Journal of Applied Linguistics \& English Literature, 5(6), 34-42. https://doi.org/ 10.7575/aiac.ijalel.v.5n.6p.34

Morett, L. (2019). The power of an image: Images, not glosses, enhance learning of concrete L2 words in beginning learners. Journal of Psycholinguistic Research, 48(3), 643-664. https://doi.org/10.1007/s10936018-9623-2

Nation, P. (2009). New roles for the L2 vocabulary. In V. Cook, \& L. Wei (Eds.), Contemporary applied linguistics: Language teaching \& learning (pp. 99-116). London: Continuum.

Nation, I. (2013). Learning vocabulary in another language (2nd ed.). Cambridge: Cambridge University Press. https://doi.org/10.1017/CBO9781139858656

Nikoopour, J., \& Kazemi, A. (2014). Vocabulary learning through digitized \& non-digitized flashcards delivery. Procedia Social \& Behavioral Sciences, 98, 1366-1373. https://doi.org/10.1016/j.sbspro.2014.03.554

O'Donnell, M. (2012). Second language learners' use of marginal glosses. Foreign Language Annals, 45(4), 543-563. https://doi.org/10.1111/j.1944-9720.2013.12004.x

Oe, Y. \& Alam, Y. (2013). Picture-based e-learning of English phrasal verbs: A comparative study of the use of pictures \& L1 glosses. International Journal of Humanities \& Arts Computing, 7, 222-233. https://doi.org/10.3366/ijhac.2013.0072

Oxford Advanced Learner's Dictionary (9th ed.). (2014). Oxford: Oxford University Press.

Öztürk, M., \& Yorganci, M. (2017). Effects of L1 \& L2 glosses on incidental vocabulary learning of EFL prep students. Electronic Turkish Studies, 12(6), 635-656.

Paivio, A. (2007). Mind \& its evolution: A dual coding theoretical approach. New York: Psychology Press.

Paivio, A. (2010). Dual coding theory \& the mental lexicon. The Mental Lexicon, 5, 205-230. https://doi.org/10.1075/ml.5.2.04pai

Poole, R. (2011). Concordance-based glosses for facilitating semantization \& enhancing productive knowledge of academic vocabulary (Unpublished master's thesis). University of Alabama.

Poole, R. (2012). Concordance-based glosses for academic vocabulary acquisition. CALICO Journal, 29(4), 679-693. https://doi.org/10.11139/cj.29.4.679-693

Poole, F., \& Sung, K. (2016). A preliminary study on the effects of an E-gloss tool on incidental vocabulary learning when reading. Chinese as a Foreign Language, 51(3), 266-285. https://doi.org/10.1075/csl.51. 3.03 poo

Rafada, S. \& Madini, A. (2017). Major causes of Saudi learners' speaking anxiety in EFL classrooms. International Journal of English Language Education, 5(1), 54-71. https://doi.org/10.5296/ijele.v5i1.10645

Rashtchi, M. \& Aghili, H. (2014). Computerized input enhancement versus computer-assisted glosses: Do they affect vocabulary recall \& retention? Theory \& Practice in Language Studies, 4(8), 1665-1674. https://doi.org/10.4304/tpls.4.8.1665-1674

Rassaei, E. (2017). Effects of three forms of reading-based output activity on L2 vocabulary learning. Language Teaching Research, 21(1), 76-95. https://doi.org/10.1177/1362168815606160

Rassaei, E. (2018). Computer-mediated textual \& audio glosses, perceptual style \& L2 vocabulary learning. Language Teaching Research, 22(6), 657-675. https://doi.org/10.1177/1362168817690183 
Razagifard, P. (2010). Effects of multimedia glosses on L2 vocabulary learning. International Journal on New Trends in Education \& their Implications, 1(3), 59-98.

Reed, S. (2010). Cognition: Theories \& application (8th ed.). Belmont, CA: Wadsworth Cengage Learning.

Rouhi, A., \& Mohebbi, H. (2012a, November). Multimedia glosses, spatial intelligence, \& L2 vocabulary learning. Paper presented at the 4th International Conference ICT for Language Learning, Firenze, Italy.

Rouhi, A., \& Mohebbi, H. (2012b). The effect of computer assisted L1 \& L2 glosses on L2 vocabulary learning. The Journal of Asia TEFL, 9(2), 1-19.

Rouhi, A. \& Mohebbi, H. (2013). Glosses, spatial intelligence, \& L2 vocabulary learning in multimedia context. Language, Linguistics, Literature, 19(2), 75-87.

Sadeghi, S. (2011). Multiple intelligence-based glossing technique. International Journal of Instructional Technology \& Distance Learning, 8(8), 3-34.

Sadoski, M., \& Paivio, A. (2013). Imagery \& text: A dual coding theory of reading \& writing $\left(2^{\text {nd }}\right.$ ed.). New York: Routledge. https://doi.org/10.4324/9780203801932

Salehi, V., \& Naserieh, F. (2013). The effects of verbal glosses on vocabulary learning \& reading comprehension. The Asian EFL Journal Quarterly, 15(3), 24-64.

Salem, E. (2006). The influence of electronic glosses on word retention \& reading comprehension with Spanish language learners (Unpublished doctoral dissertation). University of Kansas.

Sato, T. (2016). Applicability of technology-enhanced visual glosses for explicit L2 vocabulary learning: The enhancement of metaphoric competence through the learning of English polysemous words. Ampersand, 3, 43-51. https://doi.org/10.1016/j.amper.2016.03.003

Sato, T., \& Suzuki, A. (2010). Do multimedia-oriented visual glosses really facilitate EFL vocabulary learning? A comparison of planar images with three-dimensional images. Asian EFL Journal, 12(4), 160-172.

Schmitt, N. (2010). Researching vocabulary research manual. Palgrave: Macmillan. https://doi.org/10.1057/978 0230293977

Shalmani, H., \& Razmjoo, S. (2015). Multimedia annotation: Comparability of gloss modalities \& their implications for reading comprehension. Journal of English Language Teaching \& Learning, 15, 1-41.

Shalmani, H., \& Sabet, M. (2010). Pictorial, textual, \& picto-textual glosses in e-reading: A comparative study. English Language Teaching, 3(4), 195-203. https://doi.org/10.5539/elt.v3n4p195

Sun, Y., \& Yang, H. (2012). Do language proficiency \& lecture comprehension matter? Open Course Ware lectures for vocabulary learning. CALICO Journal, 29(4), 663-678. https://doi.org/10.11139/cj.29.4.663-678

Tabatabaei, O., \& Shams, N. (2011). The effect of multimedia glosses on online computerized L2 text comprehension \& vocabulary learning of Iranian EFL learners. Journal of Language Teaching \& Research, 2(3), 714-725. https://doi.org/10.4304/jltr.2.3.714-725

Taj, I., Ali, F., Sipra, M., \& Ahmad, W. (2017). Effect of technology-enhanced language learning on vocabulary acquisition of EFL learners. International Journal of Applied Linguistics \& English Literature, 6(3), 262-272. https://doi.org/10.7575/aiac.ijalel.v.6n.3p.262

Tajeddin, Z. \& Chiniforoushan, N. (2011). Visual intelligence \& lexical enhancement tasks: Their impacts on EFL learners' receptive \& productive vocabulary. The Journal of Asia TEFL, 8(3), 109-134.

Taylor, A. (2010). Glossing is sometimes a distraction: Comments on Cheng \& Good (2009). Reading in a Foreign Language, 22(2), 353-354.

Taylor, A. (2013a). CALL-based versus paper-based glosses: Is there a difference in reading comprehension? CALICO Journal, 27(1), 147-160. https://doi.org/10.11139/cj.27.1.147-160

Taylor, A. (2013b). The effects of CALL versus traditional L1 glosses on L2 reading comprehension. CALICO Journal, 23(2), 309-318. https://doi.org/10.1558/cj.v23i2.309-318

Teng, F. (2019). Retention of new words learned incidentally from reading: Word exposure frequency, L1 marginal glosses, \& their combination. Language Teaching Research. https://doi.org/10.1177/13621688198 29026

Thibeault, T. (2011). FLAn (Foreign Language Annotator) (1.2) [Computer Software]. Retrieved February 17, 2018 from http://www.redhotwords.com/downloads.html 
Tight, D. (2010). Perceptual learning style matching \& L2 vocabulary acquisition. Language Learning, 60(4), 792-833. https://doi.org/10.1111/j.1467-9922.2010.00572.x

Todd, E. (2014). The use of dictionaries, glosses, \& annotations to facilitate vocabulary comprehension for L2 learners of Russian (Unpublished master's thesis). Brigham Young University.

Tong, S. (2017, July). Effects of glosses \& involvement loads on incidental vocabulary acquisition. Paper presented at 4th International Conference on Literature, Linguistics \& Arts (ICLLA 2017), Guilin, China.

Türk, E. \& Erçetin, G. (2012). Effects of interactive versus simultaneous display of multimedia glosses on L2 reading comprehension \& incidental vocabulary learning. Computer Assisted Language Learning, 27(1), 1-25. https://doi.org/10.1080/09588221.2012.692384

Vadasy, P. \& Nelson, J. (2012). Vocabulary instruction for struggling students. New York: Guilford.

Vela, V. (2015). Using glosses for incidental vocabulary acquisition. Procedia Social \& Behavioral Sciences, 199 , 305-310. https://doi.org/10.1016/j.sbspro.2015.07.551

Wang, Y., \& Shih, S. (2015). Mobile-assisted language learning: Effects on EFL vocabulary learning. International Journal of Mobile Communications, 13(4), 358-375. https://doi.org/10.1504/IJMC.2015. 070060

Ward, E., \& Williams-Rossi, D. (2012). Jump-start your middle school students' background knowledge \& vocabulary skills. Science Scope, 35(5), 32-37.

Webb, S., \& Nation, P. (2017). How vocabulary is learned. Oxford: Oxford University Press.

Xiaohui, X. (2010). The effects of glosses on incidental vocabulary acquisition in reading. Journal of Language Teaching \& Research, 1(2), 117-120. https://doi.org/10.4304/j1tr.1.2.117-120

Yanguas, I. (2009). Multimedia glosses \& their effect on L2 text comprehension \& vocabulary learning. Language Learning \& Technology, 13, 48-67.

Yanguas, I. (2012). Task-based oral computer-mediated communication \& L2 vocabulary acquisition. CALICO Journal, 29(3), 507-531. https://doi.org/10.11139/cj.29.3.507-531

Yousefi, M., \& Biria, R. (2015). Incidental L2 vocabulary learning \& retention; types of glossing: Marginal glosses vs. endnotes. International Journal of Language Learning \& Applied Linguistics World, 9(1), 49-56.

Yun, J. (2011). The effects of hypertext glosses on L2 vocabulary acquisition: A meta-analysis. Computer Assisted Language Learning, 24(1), 39-58. https://doi.org/10.1080/09588221.2010.523285

Zhao, T., \& Ren, J. (2017). Incidental L2 lexical acquisition in reading: The role of L2-gloss frequency \& learner proficiency. The Language Learning Journal, 47(5), 608-624. https://doi.org/10.1080/09571736.2017. 1349168

Zoi, M., Bellou, I., \& Mikropoulos, T. (2011, February). Second language teaching in elementary school with a multimedia gloss. Paper presented at the International Conference on Languages, Literature, \& Linguistics, Singapore.

\section{Copyrights}

Copyright for this article is retained by the author(s), with first publication rights granted to the journal.

This is an open-access article distributed under the terms and conditions of the Creative Commons Attribution license (http://creativecommons.org/licenses/by/4.0/). 